\title{
Exploring Water Management Practices and \\ Sustainability Implications in the Bamenda Metropolis of Cameroon
}

\author{
Lucas Nyuydine Wirba (Corresponding Author) \\ Humanities and Social Science Working Group, Catholic University of Cameroon \\ (CATUC), P.O. Box, 782, Bamenda \\ E-mail: lwirba@catuc.org

\begin{abstract}
Amawa Sani Gur
Department of Geography, University of Buea, P.O. Box, 63, Buea, Cameroon

E-mail: amawasg@yahoo.com
\end{abstract}

Victor Konfor Ntoban

Humanities and Social Science Working Group, Catholic University of Cameroon (CATUC), P.O. Box, 782, Bamenda

E-mail: ntovictor@yahoo.com

\section{Bruno Lainjo Baye}

Humanities and Social Science Working Group, Catholic University of Cameroon (CATUC), P.O. Box, 782, Bamenda

E-mail: Chiefbaye@yahoo.com

\section{Emmanuel Nkembo Ngang}

Humanities and Social Science Working Group, Catholic University of Cameroon (CATUC), P.O. Box, 782, Bamenda

E-mail: enngang@googlemail.com 
Ngonga Linda Nchuone

Humanities and Social Science Working Group, Catholic University of Cameroon

(CATUC), P.O. Box, 782, Bamenda. E-mail: ngonga.linda@catuc.org

\title{
Jude Ndzifon Kimengsi
}

Department of Geography, The University of Bamenda, P.O. Box 39, Bambili,

Cameroon. E-mail: jude.kimengsi@catuc.org

Received: July 10, 2020 Accepted: September 4, 2020 Published: September 7, 2020

doi:10.5296/ijgs.v4il.17649 URL: https://doi.org/10.5296/ijgs.v4i1.17649

\begin{abstract}
City governments, the world over, are grappling with the problem of sustaining water supply to their rapidly growing population. The need to meet up with this exigency has been emphasized in Sustainable Development Goal (SDG) 6 (Ensure availability and sustainable management of water and sanitation for all) and SDG 11 (Make cities and human settlements inclusive, safe, resilient, and sustainable). While a series of demand and supply-side approaches to water management have been employed, the extent to which water management practices could guarantee (un)sustainability still require clarity, especially in the context of cities in Sub-Saharan Africa (SSA). Taking the case of the Bamenda Metropolis of Cameroon, we contribute to address this lacunae, by identifying household level water management practices in Bamenda, and discussing the implications it has for sustainable water supply (availability, affordability). To obtain relevant data for this study, a random sample of 120 households, within 8 neighborhoods of Bamenda, was conducted. Furthermore, we employed descriptive and inferential statistical methods to test the relationship between household socio-economic characteristics and water management (consumption, rationing, preservation). The results reveal the following: In terms of regularity, approximately $63 \%$ of the households have irregular water supply, and consume less than 50 litres of water per day. The key water source is pipe borne water (65\%), supplied by CAMWATER and Community Water Systems. One of the main water management practice at household level is rainwater harvesting (41.7\%), while sustainability is compromised by the weak management systems from supply side, and limited knowledge and resources at the demand side (household level). There is a need for policy (re)orientation to regulate household water distribution, consumption and affordability. Further studies are required to ground this assertion.
\end{abstract}

Keywords: Mapping, Availability, Affordability, Consumption, Sustainability, Population growth, Bamenda 


\section{Introduction}

The pace of rapid and uncontrolled urbanization in the developing world has been adequately established; most UN-Habitat reports indicate that we are living in an urban century, with more than $50 \%$ of the world's population living in cities in the developing world. This trend is even more starting in the context of sub-Saharan Africa (SSA) where people stream into unprepared urban centres (UN-Habitat, 2009; 2014; 2018). Over 450 million new urban dwellers are expected to populate cities in SSA by 2040, including emerging cities (World Bank 2013). The quest for harmonious urban development has been re-echoed in several urban development and policy circles (van Noorloos and Kloosterboer, 2018). Rapid urbanization and accompanying challenges in major cities of SSA has attracted significant attention (Abubakar and Doan, 2017; van Noorloos and Kloosterboer, 2018). Rapid urbanization demands adequate policies, technology and efficient stakeholder participation to accommodate emerging urbanization problems, such as potable water supply (Kimengsi et al., 2016; UN-Habitat, 2014). This was emphasized in the Millennium Development Goals (MDGs).

At the close of MDGs, the sustainable development goals (SDGs) further emphasized the need to cater for urban development needs of cities. For instance, SDG 11 (make cities and human settlements, inclusive, safe, resilient and sustainable) and specifically Target 11.1 (ensure access to basic urban services), all bear eloquent testimony to the increased attention being paid to secure sustainable urban services. As an evolving concept, sustainability relates to the extent to which municipal governments are able to provide basic and affordable urban services (including water) to the rapidly growing population of cities now and in the future (Amawa and Kimengsi, 2012; Kimengsi et al., 2016). It could equally denote the extent to which urban service consumers efficiently use and manage these services, while taking into consideration the aspirations of future generations. The extent to which urban services are sustainable is a function of a number of interlinked factors, including the quality of the services, the level of technology, including the management practices employed by urbanites. Of interest in this paper is the water management practices.

Historically, cities have been located around water sources to enable the flourishing of settlements. However, recent trends indicate that cities are challenged by limited water supplies. City governments are therefore grappling with the issue of providing additional water sources to the population (Batten, n.d; van Leeuwen 2015). Water governance and institutions tend to define the practices employed by urban dwellers. In effect, management practices at the demand and supply side require relevant and pragmatic action to support growing city water needs. Urban water management is therefore shaped today by interlinked forces - governance and policies, weak infrastructure, the battle to secure the right and up-to-date technology, energy demands, changing public priorities, climate change, and population growth which is believed to be the key determining factors (Figure 1). 


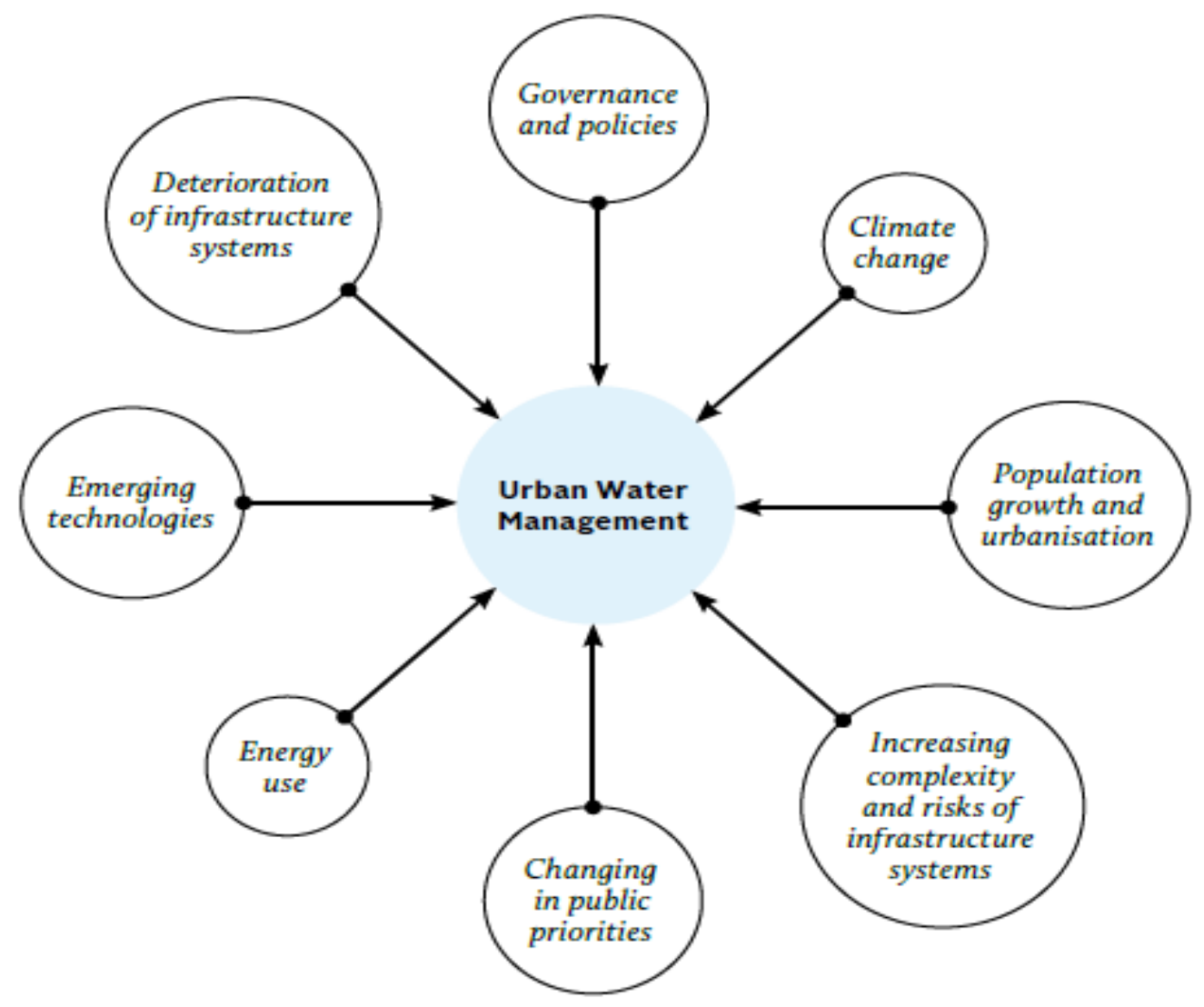

Figure 1. Interlinked forces that shape city water management

(Source: Van der Steen et al. 2011)

Strategic planning is required in the midst of such uncertainties (Van der Steen et al. 2011). There are increasing concerns about growing signs of water scarcity today. It is estimated that by 2050 , an additional $2-2.5$ billion people will populate the earth, requiring more water use at household levels and in the production of goods (Cosgrove and Loucks 2015). Effective planning requires a thorough assessment of the water management practices and their sustainability implications in growing cities. This concerns, cities in Cameroon.

Cameroonian cities are not spared with the current wave of uncontrolled and rapid urbanization. The National Institute of Statistics reports that Cameroon's population stood at about 14.5 million people in 1987 while the 2005 population census put the population at about 21 million (BUCREP, 2010). This increase has been significant in cities which register a $6 \%$ growth per annum, resulting in inequality, high unemployment rates, dysfunctional urban service systems (Kimengsi et al., 2017). While a series of demand and supply-side approaches to water management have been employed, the extent to which water management practices could guarantee (un)sustainability still require clarity, especially in the context of cities in Sub-Saharan Africa (SSA). In the context of Bamenda, several studies on urban development issues have been undertaken. For instance, the effects of urban growth on waste management (Achankeng, 2003), the hydro-geomorphological problems of urban development (Nyambod, 2010; Kometa and Ndi, 2016; Fogwe, 2016; Kimengsi et al., 2017), 


\section{Macrothink

the implications of urban growth on wetland management (Balgah and Kimengsi, 2016) planning implication of urban greening (Kimengsi and Fogwe, 2017), including strategies to develop urban water resources (Fogwe et al., 2017). However, issues of water management practices and their sustainability implications, still beg for clarity. Taking the case of the Bamenda Metropolis of Cameroon, we contribute to address this lacunae, by identifying household level water management practices in Bamenda, and discuss the implications it has for sustainable water supply (availability, affordability).

\section{Materials and Methods}

\subsection{Study Area}

Bamenda is located between latitude $5^{0} 56^{\prime}$ and $5^{0} 58^{\prime}$ North of the equator and longitude $10^{0} 08^{\prime}$ and $10^{\circ} 10^{\prime}$ of the Greenwich Meridian (Neba, 1999). It covers a surface area of 3,125 hectares (Achou- Chi, 1998). The city is bounded to the North by Santa, East by Bali, South East by Mbengwi, South West by Bafut and West by Tubah. The population of the town has been on the rise for several decades now, making it the third largest city in Cameroon. This emergence and the sustained population growth which has taken place since then, owes much to its location in the heart of the Grassfields as well as to its location in relation to the city states of Calabar, Aba, Onitsha and Enugu in Eastern Nigeria. Its central location and accessibility from the colonial regional city of Enugu were major considerations in the choice of Bamenda as the headquarters of the Bamenda Province which subsequently became the North-West Province of Cameroon (Achou-Chi, 1998). Situated at an altitude of over 2,000m, Bamenda has a fresh climate with moderate temperatures (an average of $24^{\circ} \mathrm{C}$ ) which favored human settlement through time. However, population increase and the growth of the built up area has modified the temperature, leading to an increasingly warmer trend. The annual average precipitation ranges from 1,700 to $2,824 \mathrm{~mm}$ and exhibits fluctuations which have vital significance for human occupation of the steep slopes and the flood plains. From 1976 to 1987, Bamenda's population growth rate was 7.8\%. Between 1987 and 2002, her population increased from 203480 to 257200 . As of 2015 , the population stood at 423,500 with a further projection of 1049.500 inhabitants by 2020 (National Census Data, 2018). 

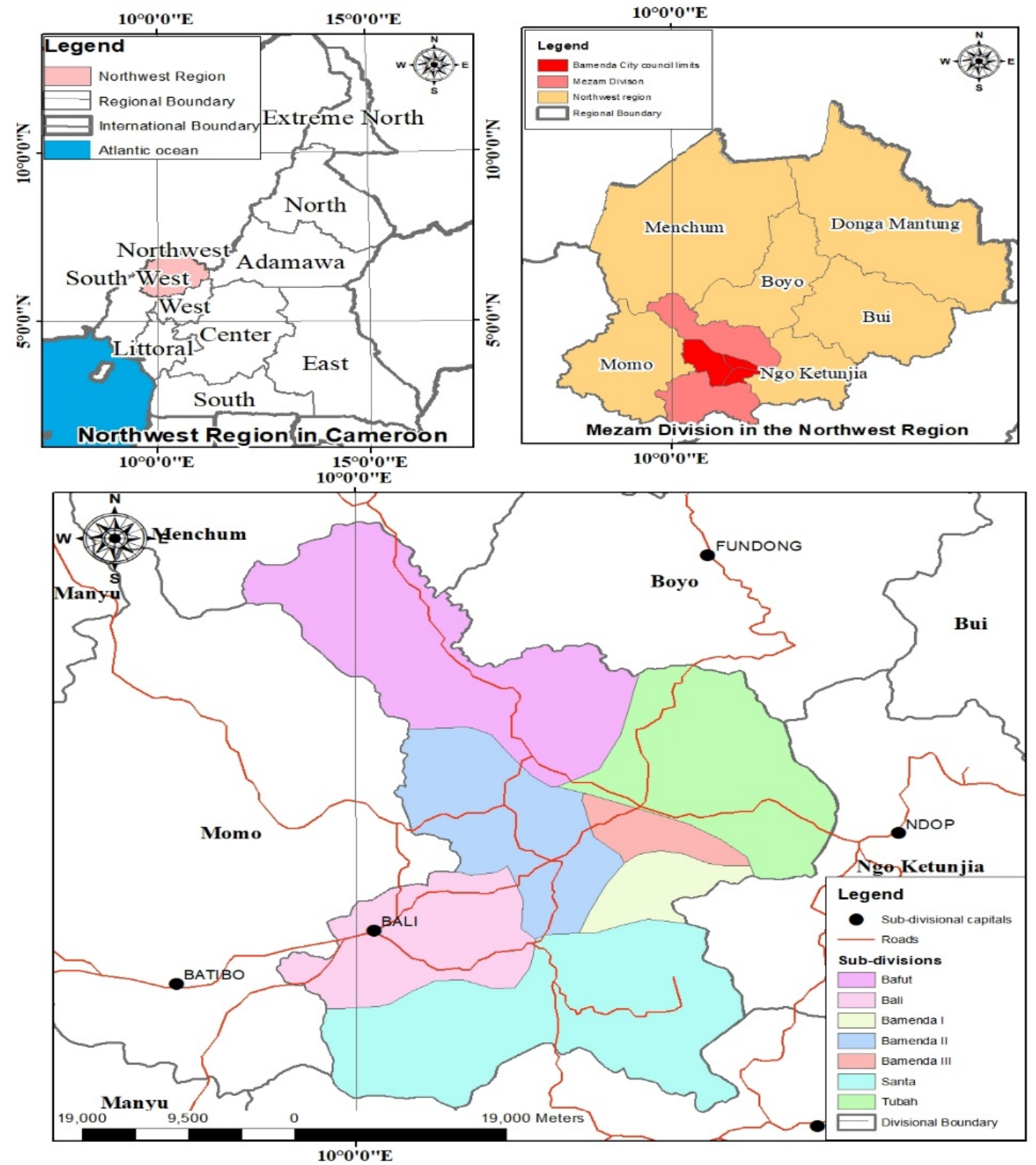

Figure 2. Location of Bamenda

Source: Administrative map of Cameroon, NIC (2011)

\subsection{Methodology}

This research is part of an on-going mixed-methods research on water governance in Cameroonian cities, under the Faculty of Humanities and Social Sciences Working Group of the Catholic University of Cameroon. Data for this study was obtained between April, May and June 2020 using two instruments - interview guides and a semi-structured questionnaire. The interview guide focused on the identification of household water sources, past and present household water management practices and their links to future water demand and use. This was then complemented by a semi-structured questionnaire which examined sustainability issues in terms of water availability, affordability, daily consumption patterns 
and the challenges thereof. The data collection process began with 10 key informant interviews in target neighborhoods of Bamenda. The key informants included members of water management committees, CAMWATER officials, quarter heads and household water consumers. These groups of people provided relevant insights on the key variables to be analyzed with respect to water management practices and sustainability. Based on the interviews, a structured questionnaire (25 items) was developed to capture measurable variables. Randomly sampled 120 household heads, from 8 neighborhoods in the three municipalities of Bamenda (Bamenda I, Bamenda II and Bamenda III). Based on the preliminary qualitative data collection, 8 neighbourhoods were purposively chosen for the study (Table 1). Within these neighbourhoods, 120 households were randomly sampled. Emphasis was placed on adult household members who have had some experience in household water use and management. Descriptive statistical techniques were employed to determine the relationship between current water management practices and their sustainability.

Table 1. Sample for the study, Bamenda Metropolis

\begin{tabular}{llc}
\hline Subdivision & Quarter & Target population \\
\hline Bamenda I & Aningdoh & 10 \\
& Ntanche & 10 \\
Bamenda I & Ntenefor & 20 \\
Bamenda II & Atuazire & 20 \\
& Ntarinkon & 15 \\
Bamenda II & Mukwebuh & 5 \\
Bamenda III & Mile 6 & 20 \\
& Mile 4 & 20 \\
Total & 8 & 120 \\
\hline
\end{tabular}

\section{Results}

\subsection{Household Size Distribution and Regularity of Water Supply}

Most of the households covered in the study had a population of below five persons, followed by those below 10 . Very few households had people above 10 (Table 2).

Table 2. Household size distribution

\begin{tabular}{ll}
\hline size of household & percentage \\
\hline$<5$ & 47.5 \\
$<10$ & 44.2 \\
$>10$ & 8.3 \\
\hline
\end{tabular}

In terms of regularity in water supply, $37.5 \%$ of the respondents reported regular water supply as opposed to $62.5 \%$ who reported an irregular water supply. Regularity is mirrored through the frequency of water cuts, the weak communication of water rationing schedules and the 


\section{Macrothink

perceived quality of water supplied. The amount of water consumed ranges from below 50 litres to above 200 litres per day. However, a majority of the households consume below 50 litres per day of water, showing that there is a critical household water situation in Bamenda (Table 3).

Table 3. Daily household water consumption

\begin{tabular}{ll}
\hline Amount in litres & Percentage \\
\hline$<50$ & 48.3 \\
$<100$ & 15.8 \\
$<150$ & 25.8 \\
$<200$ & 4.2 \\
$>200$ & 5.8 \\
\hline
\end{tabular}

\subsection{Water Sources}

Key water sources include pipe borne water (65\%), boreholes, wells and streams (Table 4). Of this, water supply from pipe borne water accounts for $65 \%$ of household water supply, while the least sources are wells and streams. Generally, the streams have been reduced to garbage receptacles, making it impossible to use the water. Although a detailed water quality analysis is not carried out yet, based on observation, the water from streams are indeed doubtful sources. To Stoker and Spencer (1977), water pollution is obvious to a casual observer especially when one appreciates the colour, smell and taste.

Table 4. Key water sources in Bamenda

\begin{tabular}{ll}
\hline Source & Percentage \\
\hline Pipe borne & 65 \\
Boreholes & 18.2 \\
Wells & 8.3 \\
Stream/river & 8.3 \\
\hline
\end{tabular}

\subsection{Water Management Practices}

\subsubsection{Practices and Challenges (Households)}

In terms of water management practices, the key storage mechanisms include drums, basins, buckets, bowls, while $41.7 \%$ of households practice rainwater harvesting - the collection and storage of rainwater in containers such as drums, buckets, basins, gallons, jerry cans and bowls. Most of the households practice water rationing during the period of water scarcity especially in the dry season. Majority of the households store water in different containers such as drums, buckets and bowls. In order to reduce the per capita water use, some households have adopted some measures such as the use of pit latrines during the day, reduction of showerheads, locking of taps after usage, water recycling and the reduction of the toilet pot tanks. During the period of water scarcity, most households complement their water needs from alternative sources such as rivers, streams, wells and boreholes and buy 
water from their neighbours and from shops. About $41.7 \%$ of the residents carry out rain harvesting by collecting and storing rainwater in containers such as drums, buckets, basins, gallons, jerry cans and bowls. Water treatment is carried out by the water authorities such as CAMWATER and community water. Furthermore, water treatment using conventional methods is carried out by the water authorities in the two water treatment centres at Mbatu and Mendakwe by CAMWATER. Community water treatment is done by the committee in charge of water management. Generally, the service providers treat, store and distribute water. They ration water during the periods of scarcity and repair all identified leakages. However, consumers always complain of being exploited through exaggerated and irregular water bills, the failures to repair burst pipes in time, and inaccessibility and general insecurity. The main challenges include irregular water supply especially by the residents of high gradient locations where water cannot reach using gravity. Some households expressed the view that water bills were expensive and exaggerated and irregular. Irregular water flow subjected the children to risks and difficulties especially of trekking for long distances to obtain water for domestic use. The storage facilities used such as drums, basins and bowls were too exposed to some health challenges. The level of communication between water authorities and households is poor especially as bills are communicated without justification.

\subsubsection{Practices and Challenges (Service Providers)}

The key service providers include CAMWATER and Community Water. CAMWATER treats, stores and distributes water to the population and has been doing this since 1979. Rationing is practiced during the periods of scarcity and minimizes leakages at the treatment plants and along the water distribution network. At the peak of the water shortage, water tanks are used to transport water to the population. This service provider is often searching for sustainable catchment sources to meet up with the increasing demand for water by the population of the Bamenda Metropolis. Community Water Systems provide water to many households that is treated at the source. They take care of maintenance and regular supply especially in Nkwen. At Mendankwe, most of the community water is raw water from CAMWATER that is treated and supplied to the population. The maintenance is carried out by a water committee which is headed by the Fon. Service providers equally encounter a lot of difficulties in carrying the repairs of burst pipes due to inaccessibility. There is constant power cuts and fuel scarcity for generators thereby inhibiting efficient water treatment and distribution. Most customers are not willing to pay their bills regularly. The constant kidnapping of workers for ransom prevents the efficient functioning of activities. There is inadequate accessibility to some sections of the distribution network. The general insecurity in terms of ghost towns, lockdowns, gunshots and fighting using arms prevent the smooth management of water in the Bamenda Metropolis.

\subsection{Sustainability Approaches}

At household level, respondents indicated that storing water in clean containers during periods of excess is one of the ways to guarantee water supply for the next days. Rainwater harvesting especially during the heavy rains and storage to reduce water scarcity is generally done. The drilling of boreholes and wells as alternative sources especially during the dry season is done to provide complementary water supply source in case of water cuts. The adoption of sustainable water use strategies such as rationing, recycling, the use of efficient 
showerheads and the reduced toilet pot tanks were also highlighted as sustainability approaches, to reduce the amount of water used, and to optimize its uses. The use of alternative catchment sources like springs, streams, rivers and lakes to meet up with the increasing population. Ensure the extension of CAMWATER services to the peripheral parts of the Bamenda Metropolis. Water authorities need to always carry out educative and sensitization programmes on the importance of water and health using the local media facilities.

Service Providers also consider the following approaches for sustainability: Putting into use the newly constructed water treatment plant which is the fruit of Sino-Cameroon cooperation. The extension of the distribution network to other sections of the Bamenda Metropolis especially to Tubah, Bafut and Bali subdivisions, and the constant search for sustainable water catchment sources to meet up with the expanding population of the Bamenda Metropolis. The increase in the population of Bamenda metropolis is putting more pressure on the urban water services especially in terms of the demand and supply of scarce water resources. This calls for a sustainable approach from urban planners and municipal authorities to plan for the future without water crisis if possible. Furthermore, climate variability and change characterized by increasing rainfall totals, higher temperatures, increase incidence of flooding are some of the challenges facing the Urban planners in the Bamenda metropolis. Migration into the Bamenda metropolis which act as a primate city in the North West Region of Cameroon, has attracted even involuntary migration of the internally displaced persons who put a lot of pressure on the city water resources. These pressures further raise sustainability questions linked to future water supply. One of the greatest challenges is in the field of governance and policies. This sector has undergone a lot of dynamics in terms of ownership and stakeholders as well as institutions. There has been a multiplicity of governance and policies since the privatization policies of the 1990s. These changes have failed to address the immediate and the future needs of urban water management in the Bamenda metropolis.

Another major challenge is the deterioration of infrastructure system. During our field work we noticed pipe breakages though in very inaccessible areas where water loss could not be immediately controlled. The present treatment plant has been in operation for 41 years with a lot of wear and tear on the infrastructure. There is a dire need for the operation of the new treatment plant to salvage this infrastructural deterioration. On the field, the galvanization of pipes was common and there is need for the modernization of the piping system to ensure clean and clear water supply to the households.

Energy use for water treatment and distribution in the Bamenda metropolis is another glaring challenge. There is constant power cuts and low voltage which cannot effectively and continuously treat and distribute water to the different areas of the metropolis. The stand by generator of the treatment plant most often lacks fuel and this hinders the efficient functioning of water treatment and distribution. There is need to upgrade the energy grid system and ensure a continuous supply of fuel during power failure to pump water during the treatment. The emerging technologies pose a serious challenge to the urban water services in the Bamenda metropolis. This sector has not been exploited and incorporated into the Bamenda urban water management system. The information technology including the 
Geographic Information System (GIS) and Remote Sensing as well as the use of Geographical Positioning System(GPS) could be integrated into the distribution network to detect burst pipes and other damages, the billing system and the payment system using electronic money system.

\section{Conclusion}

Increasing global change pressures escalating costs and risks inherent to conventional urban water management are causing cities to face ever-increasing difficulties in efficiently managing scarcer and less reliable water resources (van Leeuwen, 2015). Urban water management is shaped today by inter-linked forces of governance and policies, weak infrastructure, the grappling to secure the right and up-to-date technology, energy demand, changing public priorities, climate change and population growth. The results lead to the following conclusions: Approximately $63 \%$ of households have irregular water supply, and consume less than 50 litres of water per day. The key water source is pipe borne water $(65 \%)$, supplied by CAMWATER and Community Water Systems. One of the main water management practice at household level is rainwater harvesting $(41.7 \%)$, while sustainability is compromised by the weak management systems from supply side, and limited knowledge and resources at the demand side (household level). Water management practices in the Bamenda metropolis must meet its sustainable demand and supply if the future challenges must be achieved. The protection of all catchment areas from unscrupulous and degradation activities must be taken into consideration during any urban water planning. There is need to ensure proper security and health of the water treatment centres in terms of enclosures to prevent any encroachment.

\section{References}

Abubakar, I. R., \& Doan, P. L. (2017). Building new capital cities in Africa: Lessons for new satellite towns in developing countries. Journal of African Studies, 76(4), 546-565. https://doi.org/10.1080/00020184.2017.1376850

Achankeng, E. (2003). Globalization, Urbanization and Municipal Solid Waste Management in Africa, African Studies Association of Australasia and the Pacific. Conference-Proceedings, African on a Global Stage.

Balgah, S. N., \& Kimengsi, J. N. (2016). Land Use Dynamics and Wetland Management in Bamenda: Urban Development Policy Implications. Journal of Sustainable Development, 9(5), 1-11. https://doi.org/10.5539/jsd.v9n5p141

Batten, J. (n.d) Which Cities are best placed to Harness Water for Future Success?, Sustainable Cities Water Index ARCADIS https://www.arcadis.com/media/4/6/2 /\%7B462EFA0A-4278-49DF-9943-C067182CA682\%7DArcadis_Sustainable_Cities_Water_ Index-Web.pdf. Accessed 05.09.2019.

BUCREP. (2010). Rapport de presentation des resultats definitifs. BUCREP.

Cosgrove, W. J., \& Loucks, D. P. (2015). Water management: Current and future challenges and research directions, Water Resour. Res., 51, 4823-4839. https://doi.org/10.1002/ 2014WR016869

Fogwe, Z. N., Orock F. T., \& Samgwa, I. (2016). Developing urban Water resources and 
contamination risks on the population of Cameroon: a Bamenda example. Journal of Global Ecology and Environment, 4(2), 102-110.

Fogwe, Z. N. (2016). An Assessment of an Urban Development-Flood-Impact Relationship in a Near Millionaire City of Cameroon (Bamenda). Journal of Geoscience and Environment Protection, 4, 136-146. https://doi.org/10.4236/gep.2016.44017

Kimengsi, J. N., Mokom N. M., \& Gwan S. A. (2016). Spatial Service Accessibility and Livelihood Implications in Secondary Towns of sub-Saharan Africa: The Case of Buea, Cameroon. Open Journal of Applied \& Theoretical Environmental Sciences (OJATES), 1(1), 08-19.

Kimengsi, J. N., \& Ndam, I. (2017). Spatial variations and planning implications of urban crimes in the Bamenda Metropolis of Cameroon. Journal of Landscape Architecture and Regional Planning, 2(4), 89-98.

Kimengsi, J. N., \& Fogwe, Z. N. (2017). Urban Green Development Planning Opportunities and Challenges in sub-Saharan Africa: Lessons from Bamenda City, Cameroon. International Journal of Global Sustainability, 1(1), 1-17. https://doi.org/10.5296/ijgs.v1i1.11440

Kimengsi, J. N., Balgah, S. N., \& Achia S. N. (2017). Peri-Urban Land use Dynamics and Development Implications in the Bamenda III Municipality of Cameroon. Sustainability in Environment, 2(3), 273-288. https://doi.org/10.22158/se.v2n3p273

Kometa, S. S., \& Ndi, R. A. (2012). The Hydro-Geomorphological Implications of Urbanisation in Bamenda, Cameroon. Canadian Center of Science and Education. https://doi.org/10.5539/jsd.v5n6p64

Nyambod, E. M. (2010): Environmental Consequences of Rapid Urbanisation: Bamenda City, Cameroon. Journal of Environmental Protection, 1(1). https://doi.org/10.4236/jep. 2010.11003

Stoker, H. S., \& Seager, S. L. (1977). Organic Chemical Pollution: Petroleum, Pesticides, and Detergents. In J. O. Bockris (Ed.), Environmental Chemistry. Springer, Boston, MA. https://doi.org/10.1007/978-1-4615-6921-3_13

The World Bank. (2013). Harnessing Urbanization to End Poverty and Boost Prosperity in Africa. An Action Agenda for Transformation. Washington DC, The World Bank.

UN-Habitat. (2009). Harmonious Cities: State of the World's Cities2008/2009. London. Retrieved September 30, 2009, from www.clc.org.sg/pdf/un-habitat20Report\%20O verview.pdf

UN-Habitat (2018). The State of African Cities 2018: The geography of African investment. Nairobi: United Nations Human Settlements Programme, UN-Habitat.

UN-Habitat (2014). State of the African Cities Report: A framework for addressing urban challenges in Africa. Nairobi: United Nations Human Settlements Programme, UN-Habitat.

van Noorloos, F., \& Kloosterboer, M. (2018). Africa's new cities: The contested future of urbanization. Urban Studies, 55(6), 1223-1241. https://doi.org/10.1177/0042098017700574

Van der Steen, P., Butterworth, J., Langenbach, H., Mels, A., Rousseau, D., Smout, I. van Veenhuizen R. (2011). SWITCH Approach to Strategic planning for Integrated Urban Water Management (IUWM), http://www.switch.watsan. net/page/5007. 


\section{Macrothink}

International Journal of Global Sustainability

ISSN 1937-7924 2020, Vol. 4, No. 1

van Leeuwen, C. J. (2015): Water governance and the quality of water services in the city of Melbourne. Urban Water Journal. https://doi.org/10.1080/1573062X.2015.1086008

\section{Copyright Disclaimer}

Copyright for this article is retained by the author(s), with first publication rights granted to the journal.

This is an open-access article distributed under the terms and conditions of the Creative Commons Attribution license (http://creativecommons.org/licenses/by/4.0/). 